\title{
Pengembangan Model Pembelajaran \\ Somatic Auditory Visual Intelectualy Kinesthetic (SAVIK) \\ Terhadap Hasil Belajar Siswa
}

\author{
Zakiyah Anwar, Ruslan \\ PM FKIP UMS, PBI FKIP UMS \\ 1zakiyahanwar3377@mail.com, ${ }^{2}$ ruslanruse89@gmail.com,
}

\begin{abstract}
Abstrak
Penelitian ini bertujuan untuk mengembangkan Model Pembelajaran Somatic Auditory Visualization Intellectually Kinesthetic (SAVIK) yang valid, praktis dan efektif. Metode dalam penelitian ini adalah penelitian dan pengembangan (Research and Development), design penelitian ini menggunakan desing menurut Richey and Klein yaitu Planning (Perancangan), Production (memproduksi), Evaluation (evaluasi). Sampel penelitian ini adalah kelas VII A yang berjumlah 30 siswa. Penelitian ini memiliki produk yaitu Modul Model Pembelajaran SAVIK. Dari hasil validasi dan uji coba, Hasil penelitian menunjukkan bahwa Pengembangan model pembelajaran SAVIK telah memenuhi kevalidan sebesar 3,8, kepraktisan yaitu angket respon guru sebesar $78 \%$ dan keterlaksanaan pembelajaran dengan rata-rata 3,3 dan keefektifan yaitu hasil belajar sebesar $80 \%$ sedangkan angket respon siswa sebesar $75 \%$.dan berdasarkan implementasi model pembelajaran SAVIK menunjukkan bahwa terdapat peningkatan hasil belajar siswa sebesar 80\% atau 25 siswa yang mendapatkan nilai diatas KKM. Uji-t diperoleh $t_{\text {hitung }}$ adalah 4,288 sedangkan untuk $t_{\text {tabel }}$ adalah 1,699 dengan nilai $d f=n-1=29$. Karena $t_{\text {hitung }}>t_{\text {tabel }}$ yaitu 4,288>1,699 hal ini dapat disimpulkan bahwa terdapat peningkatan hasil belajar siswa yang nilainya diatas $K K M(60,0)$.
\end{abstract}

Kata kunci : Hasil belajar, Model pembelajaran SAVIK, Pengembangan

\section{PENDAHULUAN}

Pembelajaran yang baik adalah pembelajaran yang dapat menciptakan suasana belajar yang menyenangkan bukan hanya bagi guru tetapi juga bagi siswa itu sendiri. pembelajaran yang menyenangkan dapat tercipta apabila terdapat interaksi antara guru dan siswa, serta adanya rasa nyaman dan rasa rileks saat menerima pelajaran.

Selain itu pembelajaran yang menyenangkan terjadi jika siswa itu merasa senang dalam menerima pelajaran. Suyono dan Hariyanto (2011: 207) menyatakan bahwa siswa perlu merasa nyaman dikelas, siswa tidak boleh merasa tertekan dan merasa tegang. Ketika siswa hanya diizinkan mendengar dan melihat lalu mengerjakan soal yang sulit, tentu ini akan membebani siswa dalam belajar. Sedangkan siswa SMP merupakan siswa yang memiliki karakter anak-anak yaitu aktif. Siswa tidak akan 
sanggup diam dalam waktu yang lama. Ketika siswa diizinkan untuk mengalami secara langsung tentu ini sangat baik dalam belajar. Hal ini sejalan dengan Edgar Dale tahun 1946 tentang Kerucut Pengalaman yang menyatakan bahwa belajar yang paling baik adalah belajar melalui pengalaman langsung.

Namun, kenyataannya masih banyak siswa yang tidak menikmati belajarnya dikarenakan banyak faktor salah satunya adalah guru itu sendiri. Menurut Darmansyah (2011:6-7) pembelajaran yang tidak menyenangkan dapat berakibat munculnya stres, bosan, mengantuk, hilang motivasi, izin keluar kelas, mengobrol sesama teman dan lain sebagainya, sehingga berdampak pada hasil belajar siswa itu sndiri. Ketidaksenangan belajar akan meningkat jika mata pelajaran yang diajarkan guru bersangkutan tergolong mata pelajaran yang dianggap paling sulit.

Dari permasalahan tersebut, timbul keinginan peneliti untuk mengembangkan suatu model pembelajaran yang sekiranya mampu mengatasi masalah yang ada. Pengembangan model Pembelajaran SAVIK adalah pengembangan yang dilakukan untuk mengembangkan model pembelajaranyangsudah ada. Model pembelajaran SAVIK merupakan pembelajaran yang menggabungkan antara gerakan fisik, panca indra aktivitas intelektual serta melakukan praktek yang mungkin dapat berpengaruh terhadap pembelajaran. Kenyataannya jarang ditemukan dalam pembelajaran Matematika siswa diajak untuk melakukan praktek. Ini terjadi karena biasanya guru hanya menjelaskan pelajaran lalu menyuruh siswa mengerjakan soal tanpa mengajak siswa terlibat langsung (mengalami sendiri). Siswa akan lebih paham tentang suatu konsep dengan membaca, mendengar, dan melihat langsung suatu peristiwa. Kemudian pemahaman dan ingatan siswa terhadap apa yang dibaca, didengar, dan dilihat akan semakin meningkat ketika siswa menjelaskan konsep tersebut dan terlibat langsung dalam penyelidikan, Darman (2016).

Model pembelajaran SAVIK sendiri merupakan perpaduan unsur-unsur model pembelajaran SAVI dan model pembelajaran VAK. Model pembelajaran SAVI dan VAK memiliki kesamaan dengan Kerucut Pengalaman yang dikemukakan oleh Edgar Dale pada tahun 1946. Yohana (2011) dalam penelitiannya menyatakan bahwa melalui kerucut pengalaman dapat diketahui bahwa siswa akan mencapai hasil belajar 10\% dari apa yang ia baca, 20\% dari apa yang ia dengar, 30\% dari apa yang ia lihat, 50\% dari apa 
yang ia lihat dan dengar, $70 \%$ dari yang ia katakan, dan $90 \%$ dari yang ia lakukan. Sehingga jika kedua model ini digabungkan dapat menjadi model pembelajaran yang efektif dalam pembelajaran. Hal inilah yang mendasari pengembangan model SAVIK.

Sejalan dengan penelitian ini adalah penelitian yang dilakukan oleh Darman, D R dkk (2016) dalam penelitiannya tentang model pembelajaran SAVIR (Somatic, Auditory, Visual, Intellectual dan Repetition) yang merupakan penggabungan model pembelajaran SAVI dan AIR. Dalam penelitiannya dapat disimpulkan bahwa penggabungan dua model menjadi satu merupakan hal yang baik dilakukan untuk meningkatkan hasil belajar siswa.

\section{METODE PENELITIAN}

Penelitian pengembangan model pembelajaran SAVIK menggunakan jenis penelitian dan pengembangan (Research and Development). Design penelitian ini menggunakan design.

Pada penelitian ini yang menjadi subjek penelitian adalah SMP NEGERI 14 Raja Ampat. Dalam penelitian ini populasi yang diambil adalah keseluruhan peserta didik kelas VII, adapun pengambilan sampel dilakukan dengan cara Proportionate Stratified Random Sampling. Dimana pengambilan sampelnya memerhatikan strata (tingkatan) yang ada dalam populasi. Sehingga peneliti menjadikan kelas VIIA sebagai subjek penelitian.

Adapun istrumen data yang digunakan adalah: Lembar Validasi Model Pembelajaran SAVIK, Lembar Kepraktisan Model Pembelajaran SAVIK ( dengan menggunakan Lembar pengamatan keterlaksanaan pembelajaran), Lembar keefektifan Model Pembelajaran SAVIK (Lembar tes hasil belajar dan Angket respon siswa), Perangkat pembelajaran.

\section{HASIL DAN PEMBAHASAN}

Penelitian ini dilaksanakan di SMP NEGERI 14 Raja Ampat yang beralamat di Jl. Kimindores Kel. Sapor Danco Distrik Kota Waisai Kab. Raja Ampat Prov. Papua Barat. Penelitian ini merupakan penelitian Pengembangan dengan mengambil sampel pada siswa kelas VII A yang berjumlah 30 siswa dengan menggunakan Model 
pembelajaran SAVIK. Kegiatan penelitian ini dilaksanakan pada bulan OktoberNovember, dengan menggunakan materi Pecahan. Analisis data menggunakan metode kuantitatif. Penelitian Pengembangan yang dilakukan peneliti hanya sampai pada tahap uji coba skala kecil dikarenakan terbentur oleh waktu penelitian yang singkat. Hasil penelitian disajikan dibawah ini. Dibawah ini akan diberikan sampul dari modul yang telah di buat oleh peneliti.

1. Data Kevalidan Model Pembelajaran

Dari data kevalidan didapatkan Hasil Validasi Sintaks Model Pembelajaran pembelajaran SAVIK.

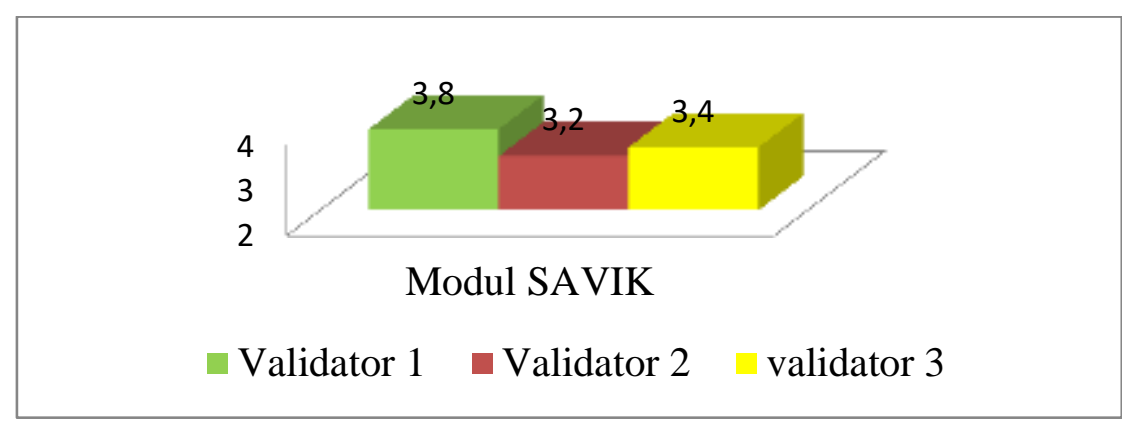

Grafik 3.1 rerata validasi Model pembelajaran SAVIK

Dari grafik diatas, dapat dilihat bahwa Model Pembelajaran SAVIK berada dalam kategori valid dilihat dari ketiga validator yang memberikan nilai diatas 3,00 dengan sedikit perubahan. Hal ini menunjukkan bahwa model tersebut sudah layak digunakan didalam kelas.

Sintaks Model Pembelajaran pembelajaran SAVIK adalah sebagai berikut:

a. Tahap Persiapan

Pada tahap ini Guru memberikan motivasi, membangkitkan semangat siswa, dan memberikan perasan positif mengenai pengalaman belajar yang akan datang.

b. Tahap Penyampaian (eksplorasi)

Pada tahap ini Guru menyampaikan materi dengan menggunakan alat peraga maupun media pembelajaran yang sesuai dengan materi yang disampaikan. Hal ini agar siswa dapat lebih memahami mengenai materi yang disampaikan.

c. Tahap penyampaian (elaborasi/pelatihan) 
Pada tahap ini guru memberikan pelatihan dalam bentuk permainan (permainan kartu joker).

1. Guru membagi siswa dalam dua kelompok besar. Setiap anggota kelompok diberikan nomor.

2. Masing-masing anggota yang memiliki nomor sama duduk disatu tempat yang sama dan diberikan kartu permainan (yang berisi kartu soal dan kartu jawaban) yang akan dikocok secara terpisah dan kemudian dibagi sama rata.

3. Permainan dimulai dengan cara salah satu siswa menjatuhkan kartu soal sedangkan lawan mainnya harus menjatuhkan kartu jawaban yang benar dengan cara mengerjakan soal tersebut.

4. Jika dalam permainan lawan berhasil menjatuhkan kartu jawaban yang benar, maka permainan itu dimenangkan oleh siswa yang menjatuhkan jawaban tersebut dan dapat memulai permainan.

5. Jika lawan tidak memegang kartu jawaban yang benar, berarti kartu jawaban berada pada pemain yang menjatuhkan kartu soal, jika demikian maka kartu soal itu dinamakan kartu Joker, otomatis pemain tersebut menjadi pemenang dan dapat menjatuhkan soal berikutnya. Kartu yang telah jatuh menjadi hak si pemenang.

6. Mainkan permainan ini hingga semua kartu di salah satu pemain habis.

d. Tahap penampilan hasil

Setelah permainan usai, anggota kelompok kembali pada kelompok masing-masing dan menghitung banyaknya anggota yang menang dalam kelompok tersebut. Setiap kelompok mempresentasikan hasil kelompoknya didepan kelas.

2. Data Kevalidan Instrument Penelitian

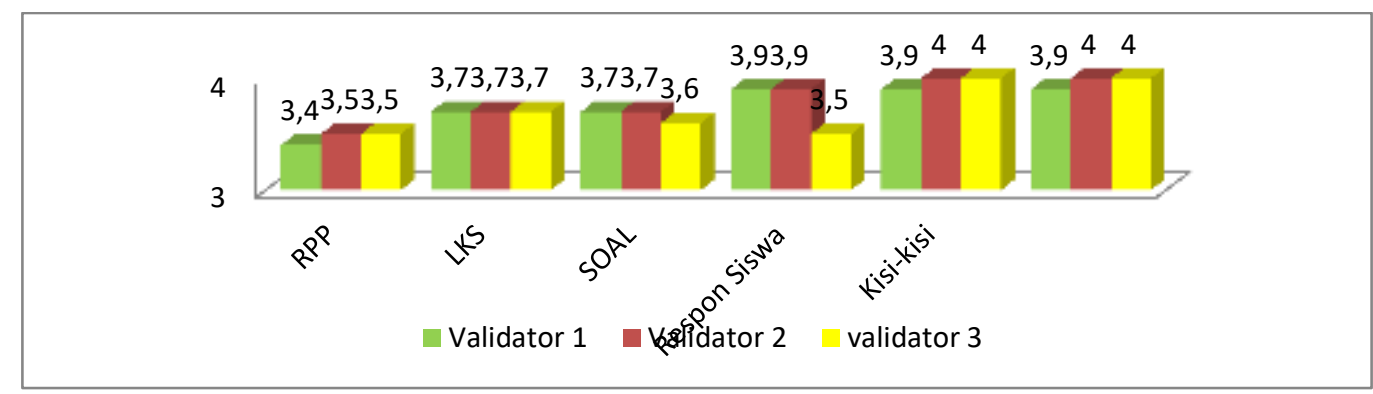

Grafik 3.2 rerata total validasi 
Pada grafik diatas menunjukkan bahwa Instrument yang divalidasi adalah Rencana Pelaksanaan Pembelajaran (RPP), Lembar Kerja Siswa (LKS), Modul Model Pembelajaran SAVIK, Soal (Pretest-postest), Angket respon siswa, Angket respon guru, Kisi-kisi, dan Lembar Keterlaksanaan Pembelajaran. Dari analisis data, didapat validasi untuk Rencana Pelaksanaan Pembelajaran (RPP) dengan nilai rerata 3,5 dengan kategori sangat Valid, Lembar Kerja Siswa (LKS) dengan nilai rerata 3,7 dengan kategori sangat Valid, Modul Model Pembelajaran SAVIK dengan nilai rerata 3,5 dengan kategori sangat Valid, Soal (Pretest-postest) dengan nilai rerata 3,7 dengan kategori sangat Valid, Angket respon siswa dengan nilai rerata 3,8 dengan kategori sangat Valid, Angket respon guru dengan nilai rerata 3,9 dengan kategori sangat Valid, Kisi-kisi dengan nilai rerata 3,9 dengan kategori sangat Valid, dan Lembar Keterlaksanaan Pembelajaran dengan nilai rerata 3,9 dengan kategori sangat Valid.

3. Data kepraktisan (Keterlaksanaan Pembelajaran)

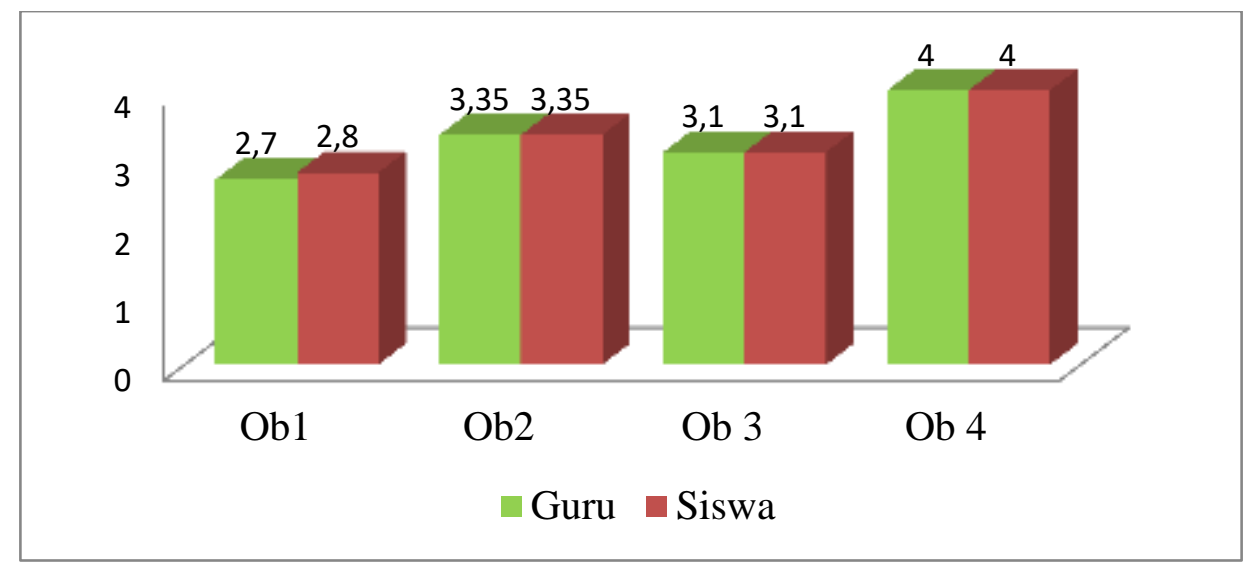

\section{Grafik 3.3 Keterlaksanaan Pembelajaran}

Pada grafik diatas menunjukkan bahwa pertemuan pertama guru (peneliti) mendapatkan nilai 2,7 hal ini terjadi disebabkan oleh guru (peneliti) belum beradaptasi dengan siswa yang diajar, selain itu guru (peneliti) terlihat gugup ketika membawakan pelajaran sehingga pelajaran kurang berjalan sesuai RPP yang berakibat skor untuk siswa tidak jauh berbeda. Pada pertemuan kedua, guru (peneliti) lebih santai dan tidak gugup dalam menghadapi siswa sehingga proses pembelajran dapat berlangsung dengan baik, pada pertemuan kedua ini, siswa mulai bisa beradaptasi dengan cepat sehingga guru dengan mudah dapat mengatur 
siswanya sesuai dengan rancangan pembelajaran yang telah disusun. Sama halnya dengan pertemuan 3-4. Dari hasil observasi pembelajaran, terlihat bahwa kegiatan pembelajaran SAVIK dari keseluruhan kegiatan yang disusun terlaksana keseluruhannya. Susunan aktivitas guru dan siswa pada setiap pertemuan yang meliputi kegiatan pendahuluan, kegiatan inti, dan kegiatan penutup berada dalam kriteria terlaksana. Hal ini sejalan dengan penelitian Afisa (2013) dalam penelitiannya yang menyatakan bahwa uji kepraktisan dalan hal ini adalah dengan menggunakan lembar observasi dapat dinyatakan berhasil apa bila nilai yang didapat dari lembar observasi berada dalam kategori minimal "baik".

4. Data keefektifan

a. Hasil Belajar

Hasil Pretest, dari 30 siswa, yang mendapatkan nilai diatas KKM sebanyak 14 siswa atau sekitar $40 \%$ siswa yang tuntas. Dan hasil posttest yang didapat setelah diberikannya perlakuan menjadi $80 \%$, yaitu sebanyak 25 siswa mendapatkan nilai diatas KKM $(60,00)$.

b. Angket respon siswa

Dari Data yang didapatkan, menunjukkan bahwa $75 \%$ siswa memberika respon sangat setuju, 22\% memberikan respon setuju, 2,4\% siswa memberikan respon tidak setuju, dan $0,6 \%$ siswa memberikan respon sangat tidak setuju terhadap pernyataan yang diberikan.

c. Uji t

Tabel 3.1 Uji T

One-Sample Test

Test Value $=60$

95\% Confidence Interval of

Mean the Difference

\begin{tabular}{|c|c|c|c|c|c|c|}
\hline & $\mathrm{T}$ & $\mathrm{df}$ & Sig. (2-tailed) & Difference & Lower & Upper \\
\hline GRUP & 4.288 & 29 & .000 & 10.500 & 5.49 & 15.51 \\
\hline
\end{tabular}

Pada tabel 3.1 terlihat bahwa nilai signifikan (sig. 2-tailed) adalah 0,00 dengan nilai signifikan $<0,05$, sehingga hal ini dapat diartikan bahwa terdapat 
peningkatan hasil belajar siswa diatas KKM (60.0) dengan menggunakan model pembelajaran SAVIK.

Berdasarkan dari uji-t diperoleh $t_{\text {hitung }}$ adalah 4,288 sedangkan untuk $t_{\text {tabel }}$ adalah 1,699 dengan nilai df $=\mathrm{n}-1=29$. Karena $t_{\text {hitung }}>t_{\text {tabel }}$ yaitu 4,288>1,699 hal ini dapat disimpulkan bahwa terdapat peningkatan hasil belajar siswa yang nilainya diatas KKM $(60,0)$.

Dari hasil uji kevalidan dari tiga validator didapatkan validatasi untuk Modul Model Pembeajaran SAVIK sebesar 3,5 dimana hal ini menujukkan bahwa model pembelajaran SAVIK berada dalam kategori Sangat Valid. Dengan nilai yang telah dicapai tersebut, maka Modul Model Pembeajaran SAVIK layak digunakan oleh guru.

Sedangkan hasil uji kepraktisan perangkat pembelajaran dengan model pembelajaran SAVIK berdasarkan pada lembar keterlaksanaan pembelajaran. Dari hasil analisis data, menunjukkan bahwa selama penerapan model pembelajaran SAVIK, termasuk dalam kategori terlaksana. Hal ini sejalan dengan penelitian yang dilakukan oleh Afisa (2013) yang menyatakan bahwa keberhasilan dalam pelaksanaan pembelajaran harus berada dalam kategori minimal "terlaksana". Disini yang memberikan skor terhadap keterlaksanaan pembelajaran adalah guru pamong yang bertugas memberi penilaian dan catatan terhadap penerapan model pembelajaran SAVIK yang dilakukan oleh peneliti.

Dari hasil uji keefektifan diperoleh dari hasil belajar yang didapat dari Pretest dan Postest yang kemudian dianalisis, didapat perbedaan yang cukup besar antara persentasi hasil Pretest (sebelum perlakuan) yaitu hanya sebesar $40 \%$ siswa yang memiliki nilai diatas $\operatorname{KKM}(60,0)$ dan persentasi hasil Postest (setelah perlakuan, yakni menggunakan model pembelajaran SAVIK) yaitu sebesar $80 \%$. Hal ini sejalan dengan penelitian yang dilakukan oleh Listiana (2013) yang menyatakan bahwa Hasil penelitian menunjukkan bahwa terdapat perbedaan yang signifikan hasil belajar IPA siswa yang dibelajarkan dengan menggunakan pendekatan pembelajaran Somatic Auditory Visual and Intellectual (SAVI) dengan siswa yang dibelajarkan dengan menggunakan 
pendekatan pembelajaran konvensional. Serta angket respon yang diberikan kepada kelas VII A, didapat hasil yang memuaskan yaitu 75\% (termasuk dalam kategori baik) merasa sangat setuju, 22\% merasa setuju, 2,4\% siswa merasa tidak setuju dan $0,6 \%$ siswa merasa sangat tidak setuju terhadap pernyataan yang diberikan. Hal ini sejalan dengan penelitian yang dilakukan oleh Afisa (2013) yang menyatakan bahwa siswa dapat menerima tindakan yang diberikan. Hal ini membuktikan bahwa model pembelajaran SAVIK telah memenuhi kriteria minimal "Baik". Berdasarkan dari Uji-t diperoleh $t_{\text {hitung }}$ adalah 4,288 sedangkan untuk $t_{\text {tabel }}$ adalah 1,699 dengan nilai df $=n-1=29$. Karena $t_{\text {hitung }}>t_{\text {tabel }}$ yaitu 4,288 $>1,699$ hal ini dapat disimpulkan bahwa terdapat peningkatan hasil belajar siswa yang nilainya diatas $\operatorname{KKM}(60,0)$. Dari data hasil tes belajar siswa, angket respon siswa dan hasil perhitungan uji-t membuktikan bahwa uji keefektifan perangkat pembelajaran telah berhasil, artinya perangkat pembelajaran dengan model pembelajaran SAVIK telah memenuhi kriteria keefektifan.

\section{KESIMPULAN}

Berdasarkan hasil analisis data dan pembahasan hasil pengembangan model pembelajaran SAVIK, maka diperoleh kesimpulan bahwa:

1. Pengembangan model pembelajaran SAVIK telah memenuhi kevalidan sebesar 3,8 , kepraktisan yaitu angket respon guru sebesar $78 \%$ dan keterlaksanaan pembelajaran dengan rata-rata 3,3 dan keefektifan yaitu hasil belajar sebesar $80 \%$ sedangkan angket respon siswa sebesar $75 \%$.

2. Berdasarkan implementasi model pembelajaran SAVIK menunjukkan bahwa terdapat peningkatan hasil belajar siswa sebesar $80 \%$ atau 25 siswa yang mendapatkan nilai diatas KKM. Dan respon siswa mencapai $75 \%$ siswa yang sangat setuju terhadap pernyataan yang diberikan. Sedangkan Uji-t diperoleh $t_{\text {hitung }}$ adalah 4,288 sedangkan untuk $t_{\text {tabel }}$ adalah 1,699 dengan nilai df $=\mathrm{n}-1=29$. Karena $t_{\text {hitung }}>t_{\text {tabel }}$ yaitu 4,288 $>1,699$ hal ini dapat disimpulkan bahwa terdapat peningkatan hasil belajar siswa yang nilainya diatas $\operatorname{KKM}(60,0)$. 


\section{Daftar Pustaka}

Afisa, N. dkk.2013. Pengembangan Perangkat Pembelajaran Model Pembelajaran Missouri Mathematics Project (Mmp) Bernuansa Kontekstual Pada Sub Pokok Bahasan Kubus Dan Balok Untuk Smp kelas VIII Semester Genap. 4 (2).

Darman, D,R. Wibowo,F,C. Suhandi, A. Rusdiana,D. 2016. Pembelajaran SAVIR dalam Mempertahankan Retensi Siswa Pada Pokok Bahasan Asas Black dan Pemuaian. http://jurnal.untirta,ac,id/index.php/Graviti 2 (1)

Fitriani, R P. 2013. Penerapan Model Pembelajaran SAVI (Somatic, Auditori, Visual, dan Intelektual).Repository.uksw.edu/bitstream.

Ghufira, S.2015. Pengaruh Model Pembelajaran Visual Auditory Kinestectik (VAK) Terhadap Aktifitas Belajar Temat Peserta Didik Kelas III SD NEGERI 1 HADUYANG Tahun Pelajaran 2015/2016. UNIVERSITAS LAMPUNG.

Irawati, WR.2012. Alternatif Pembelajaran dengan Pendekatan SAVI untuk Meningkatkan Pemecahan Siswa SD/MI Terhadap Materi Membandingkan Pecahan Sederhana. Directory/jurnal/pendidikan/dasar no 14.

Khabibah, E N. Kuswanti, N. Suparno, G. 2014. Validitas Teoritis Modul Berbasis Guided Discovery Pada Materi Respiratory System. Universitas Negeri Surabaya.

Listiana, N P N N. dkk. 2013. Pendekatan Pembelajaran Somatic Auditory Visual And Intellectual (Savi) Berpengaruh Terhadap Hasil Belajar Ipa Siswa Kelas IV Sd No.1 Kuta. Universitas Pendidikan Ganesha Singaraja, Indonesia.

Rose, C. Nicholl, M J. 2011. Accelerated Learning For The $21^{\text {ST }}$ Century.New York: Dell Publishing.

Sihwinedar,R.2015. Meningkatkan Hasil Belajar IPA Melalui Penerapan Model Pembelajaran SAVI (Somatic, Auditori, Visual, dan Intelektual) pada Siswa Kelas III SDN REJOAGUNG 01 SEMBORO Tahun Pelajaran 2013/2014. CPancaran, 4 (4)

Suhara, A M. 2013.Keefektifan Model VAK (Visual, Auditori, kinesthetic) dalam Pembelajaran Deskripptif (Studi Ekperimen Pada Siswa Kelas X SMA Negeri 1 Lawang Kidul, sumatra Selatan. Universitas Pendidikan Indonesia.

Sumawardani,W.Pasani,C F.2013.Efektifitas Model Pembelajaran SAVI dalam Pembelajaran Matematika untuk Mengembangkan Karakter Mandiri Siswa. EDU-MAT Jurnal Pendidikan Matematika.1 (1). 